\title{
Hepatocyte Growth Factor Protects Small Airway Epithelial Cells from Apoptosis Induced by Tumor Necrosis Factor- $\alpha$ or Oxidative Stress
}

\author{
MICHIYO OKADA, KANJI SUGITA, TAKESHI INUKAI, KUMIKO GOI, KEIKO KAGAMI, \\ KAZUTERU KAWASAKI, AND SHINPEI NAKAZAWA \\ Department of Pediatrics [M.O., K.S., T.I., K.G., K.Kag., S.N.], Faculty of Medicine, University of \\ Yamanashi, Tamaho, Yamanashi 409-3898, Japan, and Division of Respiratory Diseases [M.O., K.Kaw.], \\ National Center for Child Health and Development, Tokyo 157-8535, Japan
}

\begin{abstract}
Involvement of hepatocyte growth factor (HGF) in lung morphogenesis and regeneration has been established by in vitro and in vivo experiments in animals. In the present study, the protective activity of HGF against tumor necrosis factor (TNF)- $\alpha$ or hydrogen peroxide $\left(\mathrm{H}_{2} \mathrm{O}_{2}\right)$-induced damage of pulmonary epithelial cells was examined using the human small airway epithelial cell line (SAEC). Western blot analysis revealed that the receptor for HGF (c-Met) was highly expressed on the surface of SAEC and its downstream signal transduction pathway was functional. The SAEC was induced into apoptosis by the treatment with TNF- $\alpha$ or $\mathrm{H}_{2} \mathrm{O}_{2}$ in a dose-dependant manner, but was significantly rescued from apoptosis in the presence of HGF. The HGF effect was evident when added not only at the same time but also within several hours after treatment. This protective activity of HGF against the TNF- $\alpha$ - or $\mathrm{H}_{2} \mathrm{O}_{2}$-induced
\end{abstract}

ABSTRACT

apoptosis was mediated, at least in part, by up-regulating the nuclear factor $\kappa \mathrm{B}$ activity and an increase in the ratio of apoptosis-suppressing to apoptosis-inducing proteins. These results suggest that administration of HGF might exhibit a potent function in vivo for protection and improvement of acute and chronic lung injuries induced by inflammation and/or oxidative stress.

(Pediatr Res 56: 336-344, 2004)

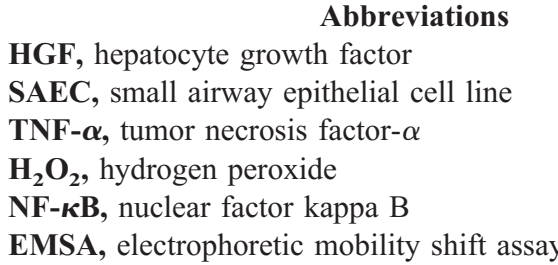

Lung development and morphogenesis begin in the fetal period of embryo and finally reach the formation of mature alveolar cells around $36 \mathrm{wk}$ of gestation. The control of lung development is complicated and known to be influenced by the interaction between pulmonary epithelial and mesenchymal cells, which is mainly mediated by autocrine and paracrine mechanisms via a variety of polypeptides expressed on or secreted from mesenchymal cells (1).

HGF, which was originally purified and cloned as a potent mitogen for mature hepatocytes in primary culture (2-4), is a cytokine mainly produced by cells of mesenchymal origin (5). Previous studies have demonstrated that HGF has multifunctional activities such as mitogenic, morphogenic, and motogenic on a variety of epithelial cells $(5,6)$, including pulmonary epithelial cells (7). Pulmonary mesenchymal cells

Received June 18, 2003; accepted February 26, 2004

Correspondence: Kanji Sugita, M.D., Department of Pediatrics, Faculty of Medicine, University of Yamanashi, 1110 Shimokato, Tamaho, Nakakoma, Yamanashi 409-3898, Japan; e-mail: ksugita@res.yamanashi-med.ac.jp

DOI: 10.1203/01.PDR.0000134255.58638.59 synthesize and secrete HGF, which has been shown to be involved not only in the formation of bronchoalveolar structure during fetal development, but also in the repair process of injured distal organs such as liver and kidney (7-10). In the bleomycin-induced lung injury model in rats (11), HGF showed the proliferative effect on type II alveolar epithelial cells, but showed the antiproliferative effect on alveolar macrophages and fibroblasts mainly implicated in the occurrence of fibrotic changes of the lung. In addition, it has recently been shown that endogenous and exogenous HGF protects cardiac myocytes in a rat model of ischemia/reperfusion injury (12) and that the addition of HGF in the culture effectively protects adult rat cardiac myocytes from oxidative stress-induced apoptosis (13). Thus, it is speculated that HGF might play a role in the physiologic repair process of respiratory epithelium after acute and chronic lung injuries.

The purpose of this study is to evaluate the rescue effect of HGF on pulmonary epithelial cells damaged by inflammation or oxidative stress using the SAEC. We showed that SAEC expressed the receptor for HGF at high levels and was significantly protected from the TNF- $\alpha$ - or $\mathrm{H}_{2} \mathrm{O}_{2}$-induced apoptosis 
by the addition of HGF. The clinical applicability of HGF for inflammation- and/or oxidative stress-mediated lung diseases, particularly in infants, is discussed.

\section{MATERIALS AND METHODS}

Cell lines. Human SAEC was obtained from Normal Human Cell Systems of Clonetics, (BioWhittaker, Walkersville, MD, U.S.A.). This line consists of normal bronchiolar epithelial cells derived from a male donor aged $25 \mathrm{y}$. The cells were cultured in polystyrene culture plate (NUNC A/S, Roskilde, Denmark) at $37^{\circ} \mathrm{C}$ in humidified $5 \% \mathrm{CO}_{2}$ air in small airway growth medium (SAGM; Sankyo Jyunyaku Co., Tokyo, Japan) with supplements containing bovine pituitary extract $(7.5 \mathrm{mg} /$ $\mathrm{mL})$, insulin $(5 \mathrm{mg} / \mathrm{mL})$, transferrin $(10 \mathrm{mg} / \mathrm{mL})$, hydrocortisone $(0.5 \mathrm{mg} / \mathrm{mL})$, triiodothyronine $(6.5 \mu \mathrm{g} / \mathrm{mL})$, human recombinant epidermal growth factor $(0.5 \mu \mathrm{g} / \mathrm{mL})$, epinephrine $(0.5 \mathrm{mg} / \mathrm{mL})$, retinoic acid $(0.1 \mu \mathrm{g} / \mathrm{mL})$, and fatty acid freeBSA $(50 \mathrm{mg} / \mathrm{mL})$. Hep-G2 (hepatocarcinoma cell line) and KOPN-57bi (B-lymphoid leukemic cell line) were used as positive and negative controls, respectively, for the c-Met expression on Western blot.

Antibodies and reagents. The disulfide-linked recombinant human HGF and TNF- $\alpha$ were purchased from R\&D Systems (Minneapolis, MN, U.S.Al) and Pepro Thec Inc. (London, England), respectively. MAb against human c-Met (intracellular domain of $\beta$ chain) and phosphotyrosine (4G10) and rabbit polyclonal antibody against $\mathrm{C}$-terminal of Gab1 were obtained from Upstate Biotechnology (Lake Placid, NY, U.S.A.). mAb against Bcl-2, Bax, and Bcl-XL were purchased from BD Biosciences (Franklin, Lakes, NJ, U.S.A.). Anti- $\alpha$-tubulin $\mathrm{MAb}$ and goat anti-NF- $\kappa \mathrm{B}$ p50 antibody were from Monosan (Uden, Netherlands) and Santa Cruz Biotechnology (Santa Cruz, CA, U.S.A.), respectively. Horseradish peroxidate-conjugated goat anti-mouse $\mathrm{IgG}$ and anti-rabbit $\mathrm{IgG}$ were from MBL (Nagoya, Japan).

Cell viability assays. Semi-confluent cells of SAEC growing in 96-well flat plates (Costar, Corning, NY, U.S.A.) were incubated for 24 and $48 \mathrm{~h}$ in triplicate with or without TNF- $\alpha$ $(20,40$, and $80 \mathrm{ng} / \mathrm{mL})$ or $\mathrm{H}_{2} \mathrm{O}_{2}(85,170$, and $340 \mu \mathrm{M})$ in the absence or presence of $\operatorname{HGF}(20,40$, and $80 \mathrm{ng} / \mathrm{mL})$, and harvested. The viability (\%) of cells in each of culture conditions was determined by trypan blue dye exclusion test.

Flow cytometric analysis. The cells were incubated for $48 \mathrm{~h}$ with or without TNF- $\alpha(40 \mathrm{ng} / \mathrm{mL})$ or $\mathrm{H}_{2} \mathrm{O}_{2}(85 \mu \mathrm{M})$ in the absence or presence of HGF $(40 \mathrm{ng} / \mathrm{mL})$ and stained with FITC-conjugated annexin $\mathrm{V}$ and propidium iodine (PI) (MEBCYTO Apoptosis Detection Kit, MBL) at room temperature for $15 \mathrm{~min}$ in dark. The signals generated by FITC and PI were analyzed using FACScan flow cytometer (Becton Dickinson Immunocytometry Systems; San Jose, CA, U.S.A.). Date acquisition and analysis were performed by the Cell Quest Program.

Western blot analysis. The cells $\left(5 \times 10^{5} / \mathrm{mL}\right)$ were incubated for $48 \mathrm{~h}$ with or without TNF- $\alpha(40 \mathrm{ng} / \mathrm{mL})$ or $\mathrm{H}_{2} \mathrm{O}_{2}(85$ $\mu \mathrm{M})$ in the absence or presence of HGF $(40 \mathrm{ng} / \mathrm{mL})$, harvested, and solubilized in lysis buffer $(50 \mathrm{mM}$ Tris-HCL, pH8.0, containing $1 \%$ Nonidet P- $40,150 \mathrm{mM} \mathrm{NaCl}, 0.05 \% \mathrm{NaN}_{3}, 5$
nM EDTA, $1 \mathrm{mM}$ PMSF, $0.2 \mathrm{TIU} / \mathrm{mL}$ aprotinin, $1 \mu \mathrm{g} / \mathrm{mL}$ pepstatin $\mathrm{A}$, and $10 \mathrm{mM}$ iodoacetamide) for $30 \mathrm{~min}$ on ice as described previously (14). Sodium vanadate $(100 \mu \mathrm{M})$ was also included in the lysis buffer in tyrosine phosphorylation experiments. The cell lysates were separated on a 7.5-12.5\% SDS-polyacrylamide gel under reducing conditions, transferred to nitrocellulose membranes (Schleicher \& Schuell, Keene, NH, U.S.A.), and were incubated with the primary antibodies against $\mathrm{Bcl}-2$ family members (Bcl-2, Bcl- $x \mathrm{~L}$, and Bax) overnight at $4^{\circ} \mathrm{C}$ followed by an incubation with horseradish peroxidase-conjugated second antibody for $1 \mathrm{~h}$ at room temperature. The detection of bands was performed using an enhanced chemiluminescence (ECL) kit (Amershan Japan, Tokyo, Japan). Changes in tyrosine phosphorylation of c-Met and Gab1 after HGF treatment was also pursued on Western blot using the specific antibody after immunoprecipitation by antiphosphotyrosine (PT) MAb and protein A beads.

$\boldsymbol{E M S A}$. EMSA of the NF- $\kappa \mathrm{B}$ activity was performed according to the method previously described (15). Before nuclear extraction, $5 \times 10^{5}$ cells were cultured with or without TNF- $\alpha(40 \mathrm{ng} / \mathrm{mL})$ or $\mathrm{H}_{2} \mathrm{O}_{2}(85 \mu \mathrm{M})$ in the absence or presence of HGF $(40 \mathrm{ng} / \mathrm{mL})$ for $48 \mathrm{~h}$ and then harvested. Ten micrograms of nuclear extracts were incubated in a $25 \mu \mathrm{L}$ volume containing $5 \mu \mathrm{L}$ of binding buffer $(10 \mathrm{mM}$ Tris, $\mathrm{pH}$ 7.5, $50 \mathrm{mM} \mathrm{NaCl}, 1 \mathrm{mM}$ EDTA, $1 \mathrm{mM}$ DTT, 4\% glycerol), $0.05 \mathrm{mg} / \mathrm{mL}$ nonspecific competitor DNA followed by an addition of ${ }^{32} \mathrm{P}$-labeled NF- $\kappa \mathrm{B}$-specific oligonucleotide (5'AGTTGAGGGGACTTTCCCAGGC-3') for $20 \mathrm{~min}$ on ice. In the competitive inhibition experiments, 100 -fold molar excess of the unlabeled consensus or $1 \mathrm{bp}$ mismatched oligonucleotide (5'-AGTTGAGGCGACTTTCCCAGGC-3') was added to the reaction mixture of nuclear extracts. For supershift analysis, antiNF- $\kappa \mathrm{B}$ p50 antibody was added to the nuclear extract and incubated for $30 \mathrm{~min}$ before the binding reaction. The samples were loaded on a $6 \%$ nondenaturing polyacrylamide gel and subjected to electrophoresis.

Morphologic examination. The cells were cultured for $48 \mathrm{~h}$ in the chamber slide (Nalge Nunc International, Naperville, IL, U.S.A.) with TNF- $\alpha(40 \mathrm{ng} / \mathrm{mL})$ or $\mathrm{H}_{2} \mathrm{O}_{2}(85 \mu \mathrm{M})$ in the absence or presence of HGF $(40 \mathrm{ng} / \mathrm{mL})$, stained with WrightGiemsa solution, and observed under microscopy.

Statistics. Differences in viability (\%) between culture conditions were analyzed by paired $t$ test and repeated-measures ANOVA (Scheffe's method) in Stat-View software (version 5; Abacus Concepts, Berkeley, CA, U.S.A.). The $p$ value $<0.05$ was considered significant.

\section{RESULTS}

SAEC expressed the functional HGF receptor. c-Met is a $190 \mathrm{kD}$ receptor of tyrosine kinase for HGF consisting of a disulfide-linked $\alpha$-subunit (50 kD) and a $\beta$-subunit (145 kD) containing the tyrosine kinase domain. We first checked the c-Met expression in SAEC on Western blot using MAb against the $\beta$-subunit of c-Met. Hep-G2 (hepatocarcinoma cell line) and KOPN57bi (B-lymphoid leukemic cell line) were used as positive and negative controls, respectively. As shown in Fig- 
A
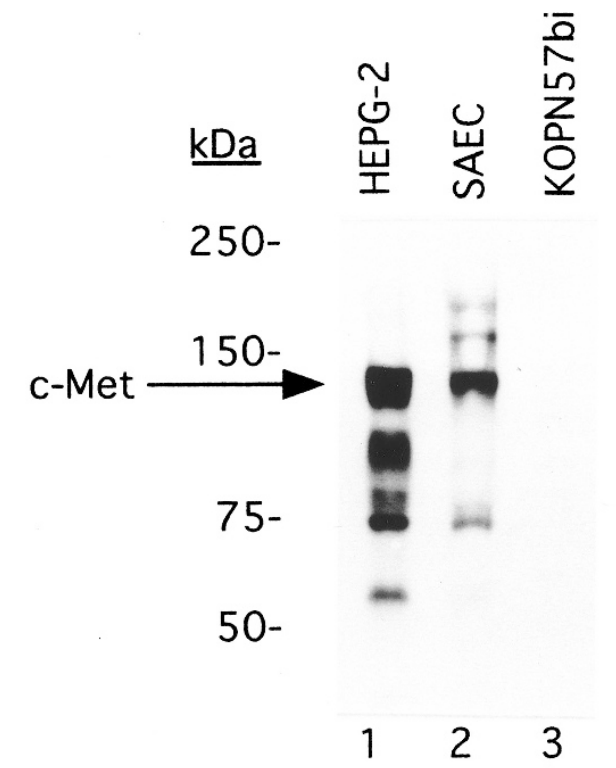

B

Gab1
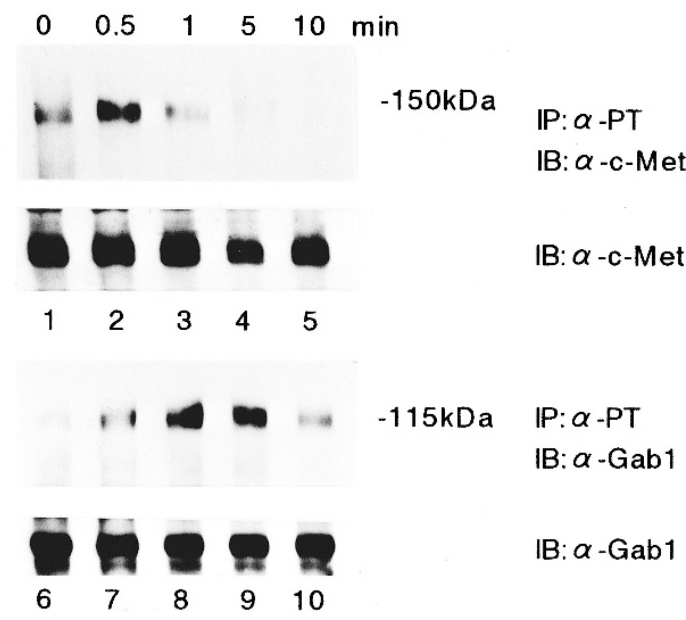

IB: $\alpha-G a b 1$

Figure 1. Expression of c-Met and tyrosine phosphorylation of c-Met and Gab1 after HGF stimulation in SAEC. (A) Expression of c-Met in SAEC. Expression of c-Met $(145 \mathrm{kD})$ in SAEC was examined on Western blot using positive and negative controls. Lane 1: Hep-G2 (positive control); lane 2: SAEC; lane 3: KOPN57bi (negative control). (B) Tyrosine phosphorylation of c-Met and Gab1 after HGF stimulation in SAEC. SAEC was preincubated for $30 \mathrm{~min}$ at $37^{\circ} \mathrm{C}$ in supplement-free medium and stimulated with HGF (100 $\mathrm{ng} / \mathrm{mL})$. Cells were harvested at different time points $(0,0.5,1,5,10$, and 30 $\mathrm{min}$ ), and tyrosine phosphorylated proteins were immunoprecipitated $(I P)$ from their lysates using anti-phosphotyrosine (PT) MAb and protein A beads. The precipitates were run on a SDS-polyacrylamide gel, and transferred to nitrocellulose membranes as described in "Materials and Methods." The membranes were immunoblotted $(I B)$ with anti-c-Met (upper) or anti-Gab1 (lower), and developed by ECL. Five microliters of each of lysates before immunoprecipitation were run and immunoblotted $(I B)$ with anti-c-Met (upper) or anti-Gab1 (lower) to show no different expression of c-Met or Gab1 in each sample.

ure $1 A$, c-Met was expressed at high levels in SAEC (lane 2), similar to that in Hep-G2 (lane 1).

c-Met is known to be phosphorylated at two tyrosine sites1349 and 1356 in the C-terminal of the $\beta$-subunit - after HGF stimulation (16). Therefore, we next examined changes in tyrosine phosphorylation of c-Met after HGF treatment on Western blot. As shown in Figure $1 B$ (upper), tyrosine- phosphorylation of c-Met was only modest before stimulation, but markedly up-regulated $30 \mathrm{~s}$ after HGF stimulation. The tyrosine phosphorylation of c-Met is known to be followed by activation of multiple signal transducers, including the docking protein Gab1, phosphatidyl inositol 3-kinase, the transcriptional factor STATs, and the adaptor protein SHC (17-21). Because it is shown that Gab1 activation via its tyrosine phosphorylation plays a central role in the HGF signaling (20, 21 ), we examined changes in tyrosine phosphorylation of Gab1 in SAEC after HGF stimulation. As shown in Figure $1 B$ (lower), Gab1 was strongly tyrosine phosphorylated upon stimulation, and its phosphorylation reached the maximal level at 1 min. Theses results indicate that the receptor for HGF is constitutively and highly expressed on the surface of SAEC and its downstream signal transduction pathway is functional.

HGF significantly inhibited the TNF- $\alpha$-induced cell death in SAEC. We next addressed a protective activity of HGF against the TNF- $\alpha$-induced cell death in SAEC. For this purpose, the cells were incubated with or without different concentrations $(20,40$, and $80 \mathrm{ng} / \mathrm{mL})$ of TNF- $\alpha$ in the absence or presence of different concentrations $(20,40$, and $80 \mathrm{ng} / \mathrm{mL})$ of HGF for different culture periods ( 24 and 48 h). Percentages of viable cells were counted by dye exclusion test in each experiment. As shown in Figure 2A, when cultured for $48 \mathrm{~h}$ in the absence of HGF, the viability significantly decreased by the treatment with TNF- $\alpha$ in a dose-dependent manner (from 85.7 $\pm 3.0 \%$ to $53.3 \pm 5.1 \%$ at $80 \mathrm{ng} / \mathrm{mL}$ of TNF- $\alpha$ ), but, it was significantly recovered in the presence of HGF $(40 \mathrm{ng} / \mathrm{mL})$ from $72.6 \pm 3.0 \%$ to $79.3 \pm 3.5 \%$ at $20 \mathrm{ng} / \mathrm{mL}$ of TNF- $\alpha$, from $60.3 \pm 5.5 \%$ to $75.6 \pm 1.5 \%$ at $40 \mathrm{ng} / \mathrm{mL}$, and from $53.3 \pm$ $5.1 \%$ to $68.2 \pm 7.7 \%$ at $80 \mathrm{ng} / \mathrm{mL}$. When cultured at $40 \mathrm{ng} / \mathrm{mL}$ of TNF- $\alpha$, a significant inhibition of cell death by the addition of $40 \mathrm{ng} / \mathrm{mL}$ of HGF was observed up to $48 \mathrm{~h}$ of culture period (Fig. $2 B$ ). When cultured for $48 \mathrm{~h}$ at $80 \mathrm{ng} / \mathrm{mL}$ of TNF- $\alpha$, a significant inhibition of cell death was documented by the addition of HGF in a dose-dependant fashion (up to $40 \mathrm{ng} / \mathrm{mL}$ ) (Fig. 2C). These results indicate that HGF has a protective activity against the TNF- $\alpha$-induced cell death in SAEC.

HGF significantly inhibited the hydrogen peroxideinduced cell death in SAEC. We next addressed whether HGF also has a protective activity against $\mathrm{H}_{2} \mathrm{O}_{2}$-induced cell death in SAEC. For this purpose, the cells were incubated with or without different concentrations $(85,170$, and $340 \mu \mathrm{M})$ of $\mathrm{H}_{2} \mathrm{O}_{2}$ in the absence or presence of different concentrations (20,40, and $80 \mathrm{ng} / \mathrm{mL})$ of HGF for different culture periods (24 and $48 \mathrm{~h}$ ). When cultured for $48 \mathrm{~h}$ in the absence of HGF, the viability significantly decreased in a dose-dependant fashion of $\mathrm{H}_{2} \mathrm{O}_{2}$, but it was significantly recovered by the addition of HGF $(40 \mathrm{ng} / \mathrm{mL})$ as follows: from $49.6 \pm 6.4 \%$ to $67.6 \pm 4.0 \%$ at $85 \mu \mathrm{M} \mathrm{H}_{2} \mathrm{O}_{2}$, from $44.3 \pm 2.5 \%$ to $58.6 \pm 5.6 \%$ at $170 \mu \mathrm{M}$ $\mathrm{H}_{2} \mathrm{O}_{2}$, and from $27.6 \pm 2.5 \%$ to $44.0 \pm 7.8 \%$ at $340 \mu \mathrm{M} \mathrm{H}_{2} \mathrm{O}_{2}$ (Fig. $3 A$ ). A significant inhibition of cell death by $\mathrm{HGF}$ was observed up to $48 \mathrm{~h}$ when cultured at $170 \mu \mathrm{M} \mathrm{H}_{2} \mathrm{O}_{2}$ in the presence of $40 \mathrm{ng} / \mathrm{mL}$ of HGF (Fig. $3 B$ ) and in a dosedependant manner of $\mathrm{HGF}$ (up to $40 \mathrm{ng} / \mathrm{mL}$ ) when cultured for $48 \mathrm{~h}$ at $340 \mu \mathrm{M} \mathrm{H}_{2} \mathrm{O}_{2}$ (Fig. $3 C$ ). These results indicate that HGF protects SAEC from oxidative stress-induced cell death. 
A

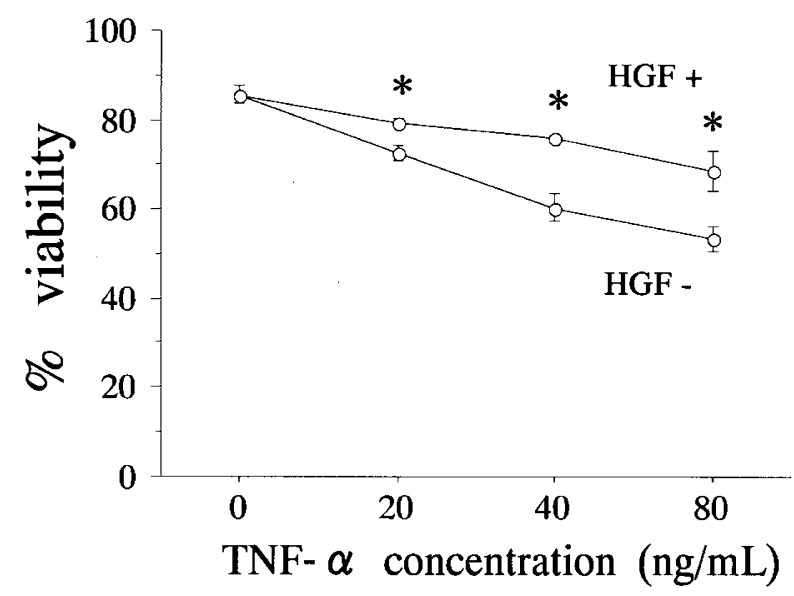

B

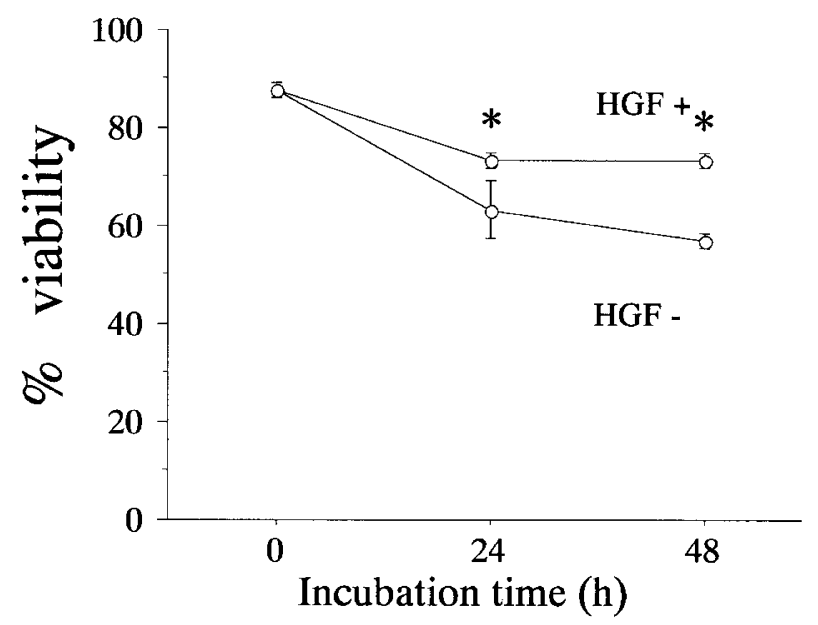

C

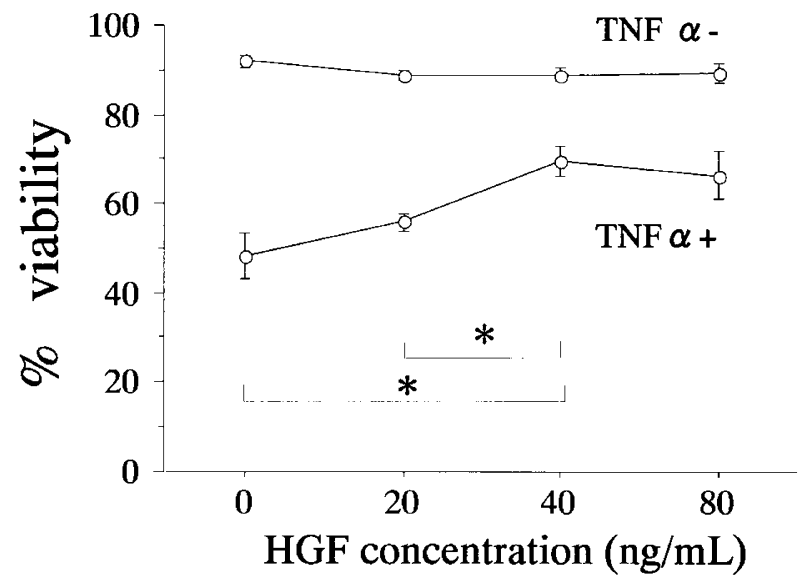

Figure 2. Analysis of viability (\%) of SAEC after TNF- $\alpha$ treatment in the absence or presence of HGF by dye exclusion test. The result is a representative from three distinct experiments, and the data were expressed as mean (open circle) $\pm \mathrm{SD}$ (error bar) in the analysis performed in triplicate. Asterisks show significant $(p<0.01)$ differences between HGF + and HGF - cultures. (A) Effect of TNF- $\alpha$ concentration. SAEC was incubated for $48 \mathrm{~h}$ with different concentrations $(0,20,40$, and $80 \mathrm{ng} / \mathrm{mL})$ of TNF- $\alpha$ in the absence (HGF - ) or presence $(\mathrm{HGF}+)$ of HGF $(40 \mathrm{ng} / \mathrm{mL})$. (B) Effect of culture period. SAEC was incubated for different culture periods $(0,24$, and $48 \mathrm{~h})$ with TNF- $\alpha(40$ $\mathrm{ng} / \mathrm{mL})$ in the absence $(\mathrm{HGF}-)$ or presence $(\mathrm{HGF}+)$ of $\mathrm{HGF}(40 \mathrm{ng} / \mathrm{mL}) .(C)$ Effect of HGF concentration. SAEC was incubated for $48 \mathrm{~h}$ with different concentrations $(0,20,40$, and $80 \mathrm{ng} / \mathrm{mL})$ of HGF in the absence (TNF- $\alpha-)$ or presence (TNF- $\alpha+)$ of TNF- $\alpha(80 \mathrm{ng} / \mathrm{mL})$.
A

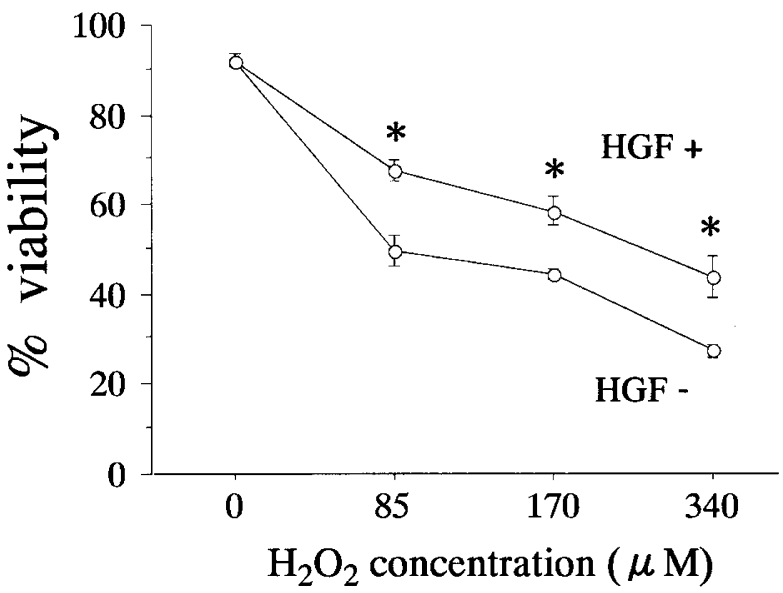

B

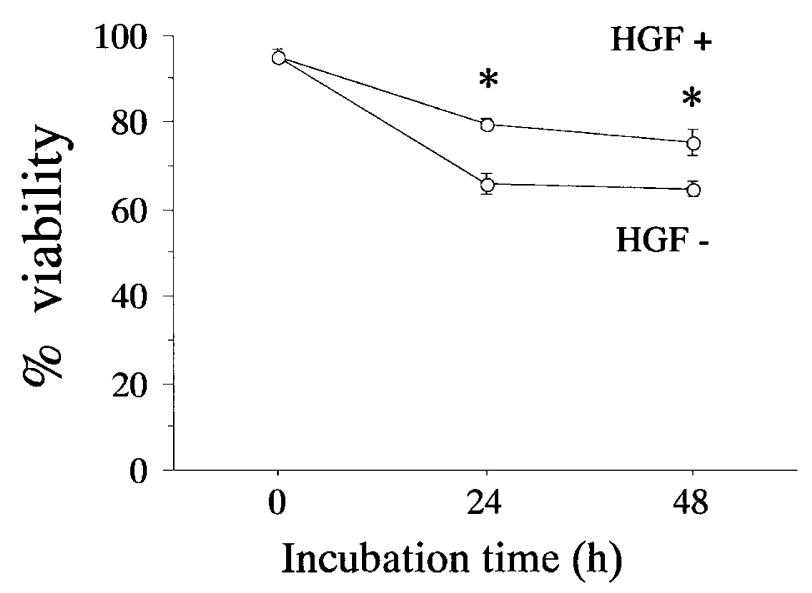

C

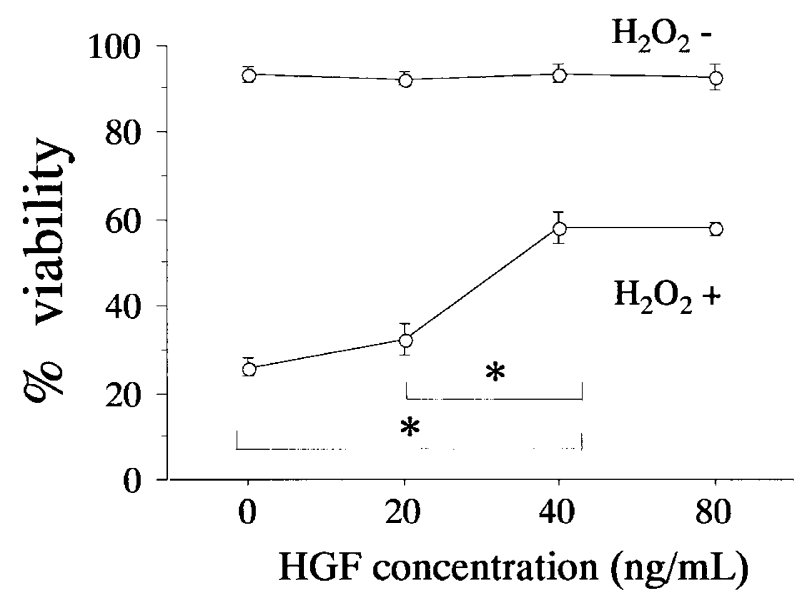

Figure 3. Analysis of viability (\%) of SAEC after $\mathrm{H}_{2} \mathrm{O}_{2}$ treatment in the absence or presence of HGF by dye exclusion test. The result is a representative from three distinct experiments, and the data were expressed as mean (open circle) $\pm \mathrm{SD}$ (error bar) in the analysis performed in triplicate. Asterisks show significant $(p<0.01)$ differences between HGF + and HGF- cultures. $(A)$ Effect of $\mathrm{H}_{2} \mathrm{O}_{2}$ concentration. SAEC was incubated for $48 \mathrm{~h}$ with different concentrations $(0,85,170$, and $340 \mu \mathrm{M})$ of $\mathrm{H}_{2} \mathrm{O}_{2}$ in the absence (HGF-) or presence $(\mathrm{HGF}+)$ of HGF $(40 \mathrm{ng} / \mathrm{mL})$. (B) Effect of culture period. SAEC was incubated for different culture periods $(0,24$, and $48 \mathrm{~h})$ with $\mathrm{H}_{2} \mathrm{O}_{2}(85 \mu \mathrm{M})$ in the absence $(\mathrm{HGF}-)$ or presence $(\mathrm{HGF}+)$ of HGF $(40 \mathrm{ng} / \mathrm{mL})$. (C) Effect of HGF concentration. SAEC was incubated for $48 \mathrm{~h}$ with different concentrations $(0,20,40$, and $80 \mathrm{ng} / \mathrm{mL})$ of HGF in the absence $\left(\mathrm{H}_{2} \mathrm{O}_{2}-\right)$ or presence $\left(\mathrm{H}_{2} \mathrm{O}_{2}+\right)$ of $\mathrm{H}_{2} \mathrm{O}_{2}(340 \mu \mathrm{M})$. 
$\mathrm{HGF}$ protects $\mathrm{SAEC}$ from $\mathrm{TNF}-\alpha$ - or $\mathrm{H}_{2} \mathrm{O}_{2}$-induced cell death when added within several hours after treatment. To examine the protective activity of HGF when added after treatment with TNF- $\alpha$ or $\mathrm{H}_{2} \mathrm{O}_{2}$, HGF $(40 \mathrm{ng} / \mathrm{mL})$ was included in the culture simultaneously and 1,3 , and $6 \mathrm{~h}$ after treatment with TNF- $\alpha(40 \mathrm{ng} / \mathrm{mL})$ or $\mathrm{H}_{2} \mathrm{O}_{2}(85 \mu \mathrm{M})$, and the viability of SAEC was evaluated after 24 and $48 \mathrm{~h}$ incubation. As shown in Figure 4, a significant protective activity was observed after both 24 and $48 \mathrm{~h}$ incubation whenever HGF was included in the culture after treatment with TNF- $\alpha$ or $\mathrm{H}_{2} \mathrm{O}_{2}$. Importantly, the protective activity of HGF did not decline when HGF was added within $6 \mathrm{~h}$ from the start of TNF- $\alpha$ treatment, and within $3 \mathrm{~h}$ from the start of $\mathrm{H}_{2} \mathrm{O}_{2}$ treatment. These results indicate that HGF exerts a protective activity in SAEC even after the death

A

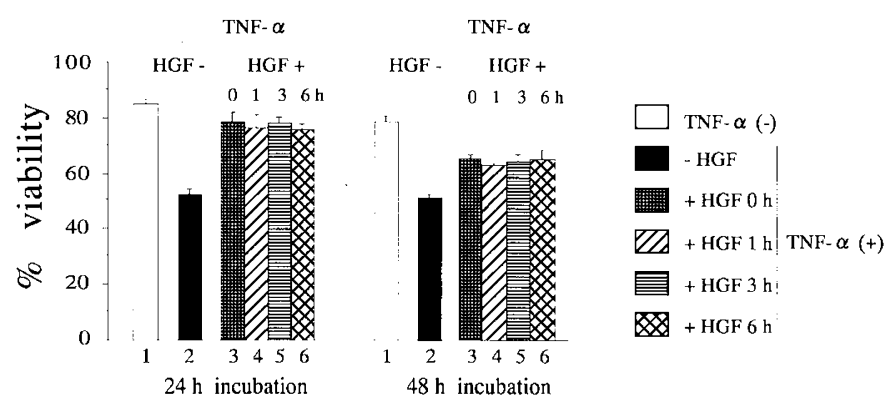

B

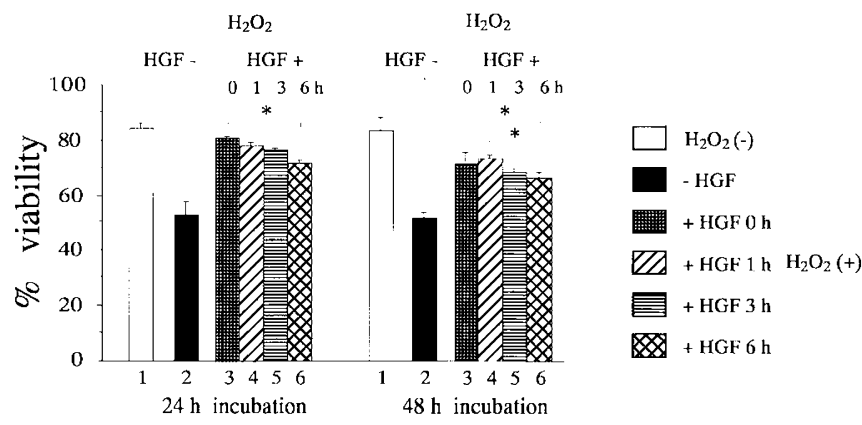

Figure 4. Analysis of protective effect of HGF in SAEC when added after the treatment with TNF- $\alpha$ or $\mathrm{H}_{2} \mathrm{O}_{2}$. Viability (\%) of SAEC was examined by dye exclusion test at 24 (left columns) and $48 \mathrm{~h}$ (right columns) of incubation. The result is a representative from three distinct experiments, and the data were expressed as mean (open circle) $\pm \mathrm{SD}$ (error bar) in the analysis performed in triplicate. $(A) \mathrm{TNF}-\alpha$ treatment. SAEC was treated with TNF- $\alpha(40 \mathrm{ng} / \mathrm{mL})$, and HGF $(40 \mathrm{ng} / \mathrm{mL})$ was added simultaneously and 1,3 , and $6 \mathrm{~h}$ later. Column 1: no TNF- $\alpha$ treatment; column 2: TNF- $\alpha$ treatment without the addition of HGF; columns 3, 4, 5, and 6: TNF- $\alpha$ treatment with the addition of HGF simultaneously and 1,3 , and $6 \mathrm{~h}$ later, respectively. Significant $(p<0.01)$ protective effects were observed in all of HGF + cultures (column $2 \mathrm{vs}$ columns $3-6)$ at 24 and $48 \mathrm{~h}$ incubation. No significant differences of protective effects were observed between $\mathrm{HGF}+$ cultures (columns 3-6) at 24 and $48 \mathrm{~h}$ incubation. $(B) \mathrm{H}_{2} \mathrm{O}_{2}$ treatment. SAEC was treated with $\mathrm{H}_{2} \mathrm{O}_{2}(85 \mu \mathrm{M})$, and HGF $(40 \mathrm{ng} / \mathrm{mL})$ was added simultaneously and 1,3 , and $6 \mathrm{~h}$ later. Column 1: no $\mathrm{H}_{2} \mathrm{O}_{2}$ treatment; column 2: $\mathrm{H}_{2} \mathrm{O}_{2}$ treatment without the addition of HGF; columns 3, 4, 5, and 6: $\mathrm{H}_{2} \mathrm{O}_{2}$ treatment with the addition of HGF simultaneously and 1,3 , and $6 \mathrm{~h}$ later, respectively. Significant $(p<0.01)$ protective effects were observed in all of HGF+ cultures (column 2 vs columns 3-6) at 24 and $48 \mathrm{~h}$ of incubation. Asterisks show significant $(p<0.05)$ decreases in protective effects observed between HGF + cultures; column 3 vs column 6 at $24 \mathrm{~h}$ incubation, and columns 3 and 4 vs column 6 at $48 \mathrm{~h}$ incubation. signal delivered from TNF- $\alpha$ or $\mathrm{H}_{2} \mathrm{O}_{2}$ is fully transmitted to cells.

Protective activity of HGF in SAEC is mediated by mainly inhibiting apoptosis but not necrosis. The dye exclusion test might detect cell death by either apoptosis or necrosis or both. We attempted to tentatively address whether the protective activity of HGF against cell death of SAEC is mediated by the inhibition of apoptosis or necrosis. When the cells were incubated for $24 \mathrm{~h}$ with $780 \mu \mathrm{M} \mathrm{H} \mathrm{H}_{2} \mathrm{O}_{2}$, whose concentration is known to induce necrosis of a variety of cells, in the absence of presence of HGF $(40 \mathrm{ng} / \mathrm{mL})$, the protective activity of HGF was no longer observed; $16.0 \pm 2.0 \%$ of viability in the absence of HGF and $15.0 \pm 1.0 \%$ in the presence of HGF. In contrast, when the cells were incubated for $24 \mathrm{~h}$ with $25 \mathrm{nM}$ staurosporine, which is reported to induce apoptosis of human vascular endothelial cells (22), in the absence of presence of HGF $(40 \mathrm{ng} / \mathrm{mL})$, the marked protective activity of HGF was documented; $26.8 \pm 6.3 \%$ of viability in the absence of HGF versus $73.0 \pm 2.6 \%$ in the presence of HGF. These results suggest that the protective activity of HGF in SAEC might be mediated by mainly inhibiting apoptosis but not necrosis.

$H G F$ protected $S A E C$ from apoptosis induced by TNF- $\alpha$ or hydrogen peroxide. It is known that ligation of type I receptor (TNF-R1) by TNF- $\alpha$ results in recruitment of a cytoplasmic adaptor molecule FADD via TRADD to the death domain of the receptor, leading to activation of caspase- 8 , which subsequently initiates proteolytic activation of downstream effector caspases such as caspase- 3 and -7 , and finally induces apoptosis (23). It is also known that oxidative stress induces a variety of cells into apoptosis by several apoptosisinducing mechanisms such as activation of extracellular signalregulated kinases including c-jun-N-terminal kinase (JNK) and p38, up-regulation of apoptosis-inducing proteins expression, and down-regulation of the NF- $\kappa \mathrm{B}$ activity (24-26). To further biologically assess a decrease in cellular viability of SAEC after TNF- $\alpha$ or $\mathrm{H}_{2} \mathrm{O}_{2}$ treatment and its partial restoration by the addition of HGF, we performed apoptosis detection analysis with a flow cytometer using FITC-conjugated annexin-V and $\mathrm{PI}$ as shown in Figure 5. When the cells were treated with TNF- $\alpha(40 \mathrm{ng} / \mathrm{mL})$ and $\mathrm{H}_{2} \mathrm{O}_{2}(85 \mu \mathrm{M})$, respectively, in the absence of HGF, the apoptotic population stained with both FITC and PI reached $42.1 \%$ and $32.9 \%$, respectively, which decreased to $16.9 \%$ and $17.5 \%$, respectively, in the presence of HGF $(40 \mathrm{ng} / \mathrm{mL})$. These results suggest that HGF exerts an antiapoptotic function against the TNF- $\alpha$ - or $\mathrm{H}_{2} \mathrm{O}_{2}$-induced apoptosis in SAEC.

HGF protected SAEC with distinct morphologic changes from the TNF- $\alpha$ or $\mathrm{H}_{2} \mathrm{O}_{2}$-induced apoptosis. To evaluate the inhibition mechanism of apoptosis by HGF, we first observed morphologic changes of SAEC in the absence or presence of HGF $(40 \mathrm{ng} / \mathrm{mL})$ after $48 \mathrm{~h}$ treatment with TNF- $\alpha(40 \mathrm{ng} / \mathrm{mL})$ or $\mathrm{H}_{2} \mathrm{O}_{2}(85 \mu \mathrm{M})$ (Fig. 6). The cells growing in the SAGM culture medium were adherent to plastic and round in shape (Fig. 6A). The addition of HGF alone did not affect shape, viability, and proliferative activity of SAEC (Fig. $6 B$ ). After TNF- $\alpha$ or $\mathrm{H}_{2} \mathrm{O}_{2}$ treatment, the cells markedly lost their adherent activity and showed features characteristic of apoptosis such as cell shrinkage and fragmented nuclei (Fig. 6, $C$ and $E$ ). 
Treatment $(-)$

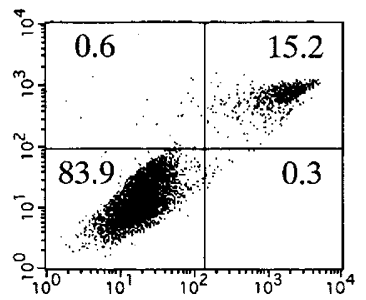

Treatment (-)

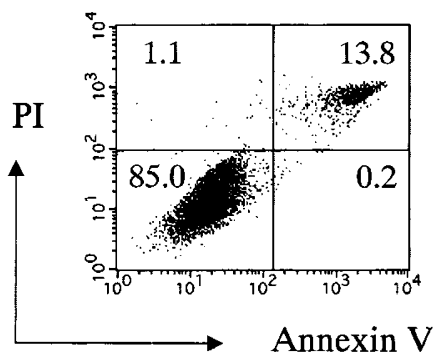

TNF- $\alpha$

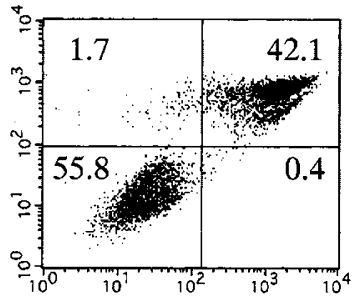

$\mathrm{H}_{2} \mathrm{O}_{2}$

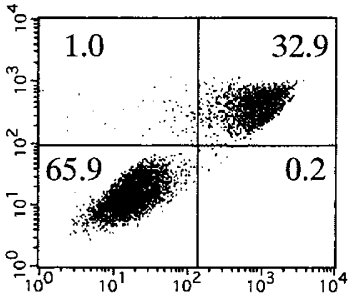

TNF- $\alpha+\mathrm{HGF}$

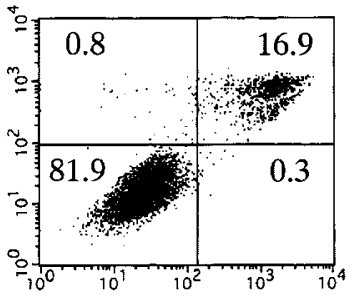

$\mathrm{H}_{2} \mathrm{O}_{2}+\mathrm{HGF}$

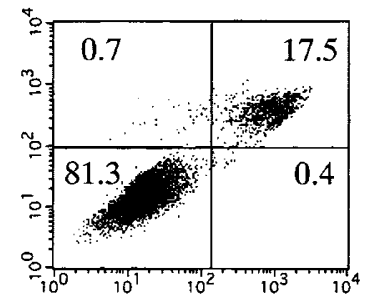

Figure 5. Flow cytometric analysis of HGF effect on TNF- $\alpha$ - or $\mathrm{H}_{2} \mathrm{O}_{2}$-induced apoptosis in SAEC. SAEC was cultured for $48 \mathrm{~h}$ with TNF- $\alpha$ ( $\left.40 \mathrm{ng} / \mathrm{mL}\right)$ or $\mathrm{H}_{2} \mathrm{O}_{2}(85 \mu \mathrm{M})$ in the absence or presence of HGF $(40 \mathrm{ng} / \mathrm{mL})$, stained with FITC-conjugated annexin V and PI, and analyzed on flow cytometer. Horizontal and vertical axes represent log fluorescence intensities of FITC and PI, respectively.

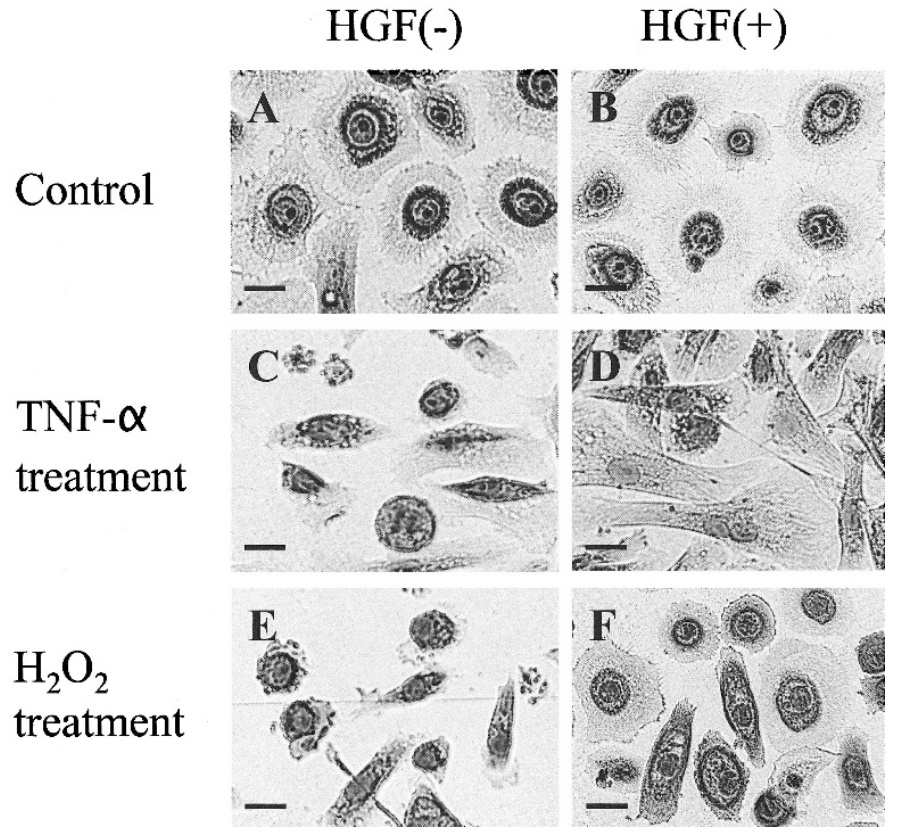

Figure 6. Effect of HGF on morphologic changes of SAEC after TNF- $\alpha$ or $\mathrm{H}_{2} \mathrm{O}_{2}$ treatment. SAEC was cultured for $48 \mathrm{~h}$ with TNF- $\alpha(40 \mathrm{ng} / \mathrm{mL})$ or $\mathrm{H}_{2} \mathrm{O}_{2}$ $(85 \mu \mathrm{M})$ in the absence or presence of HGF $(40 \mathrm{ng} / \mathrm{mL})$, stained, and observed under microscopy. Scale bars indicate $10 \mu \mathrm{m}$. $(A)$ control culture; $(B)$ culture with HGF alone; $(C)$ culture with TNF- $\alpha$ in the absence of HGF; $(D)$ culture with TNF- $\alpha$ in the presence of HGF; $(E)$ culture with $\mathrm{H}_{2} \mathrm{O}_{2}$ in the absence of HGF; $(F)$ culture with $\mathrm{H}_{2} \mathrm{O}_{2}$ in the presence of HGF

Of interest, the cells rescued from the TNF- $\alpha$-induced apoptosis by HGF were strongly stretched into a fibroblast-like appearance (Fig. 6D), whereas most cells rescued from the $\mathrm{H}_{2} \mathrm{O}_{2}$-induced apoptosis by $\mathrm{HGF}$ remained round in shape (Fig. 6F). Even when HGF was added several hours after treatment with TNF- $\alpha$ or $\mathrm{H}_{2} \mathrm{O}_{2}$, morphologic features were almost identical (data not shown).
Anti-apoptotic activity of HGF was mediated by, at least in part, up-regulation of the NFKB activity and altered expression of Bcl-2 family members. It is known that TNF- $\alpha$ transmits not only the death signal mediated by the death domain of the receptor, but also the survival signal by up-regulating the endogenous NF- $\kappa \mathrm{B}$ activity via the interaction of the receptor with adaptor proteins such as RIP and TRAF2, and that whether cells are induced into apoptosis or remain surviving is regulated by the balance between the death and survival signals (23). It is also known that oxidative stress down-regulates the $\mathrm{NF}-\kappa \mathrm{B}$ activity by suppressing breakdown of $\mathrm{I} \kappa \mathrm{B}$ (inhibitor of $\mathrm{NF}-\kappa \mathrm{B})$ (27). Therefore, to shed light on the mechanism of a protective activity of HGF against the TNF- $\alpha$ or $\mathrm{H}_{2} \mathrm{O}_{2}$-induced apoptosis, we examined the effect of HGF $(40 \mathrm{ng} / \mathrm{mL})$ on the DNA-binding activity of NF- $\kappa \mathrm{B}$ using EMSA. In untreated SAEC, HGF did not show a significant effect on the NF- $\kappa \mathrm{B}$ activity (Fig. $7 A$ ). However, as shown in Figure $7 B$, the slightly increased NF- $\kappa$ B activity after treatment with $40 \mathrm{ng} / \mathrm{mL}$ of TNF- $\alpha$ (lanes $5-8$ ) was modestly but further up-regulated by the addition of HGF (lanes 9-12). As shown in Figure $7 C$ (longer exposure), treatment with $\mathrm{H}_{2} \mathrm{O}_{2}(85 \mu \mathrm{M})$ inhibited the NF- $\kappa \mathrm{B}$ activity (lanes 5-8), but the addition of HGF moderately canceled its inhibition (lanes 9-12), although supershift of the band by anti-p50 antibody was incomplete (lane 12), suggesting that subunit(s) other than $\mathrm{p} 50$ also participate in an increase in the NF- $\kappa \mathrm{B}$ activity by HGF. These results suggest that up-regulation of the NF- $\kappa \mathrm{B}$ activity is implicated in a protective activity of HGF on the TNF- $\alpha$ - or $\mathrm{H}_{2} \mathrm{O}_{2}$-induced apoptosis.

Susceptibility of normal and cancer cells to induction of apoptosis is regulated by the balance of expression between apoptosis-suppressing and apoptosis-inducing proteins. Antiapoptotic proteins such as Bcl-2 and Bcl-XL that reside 

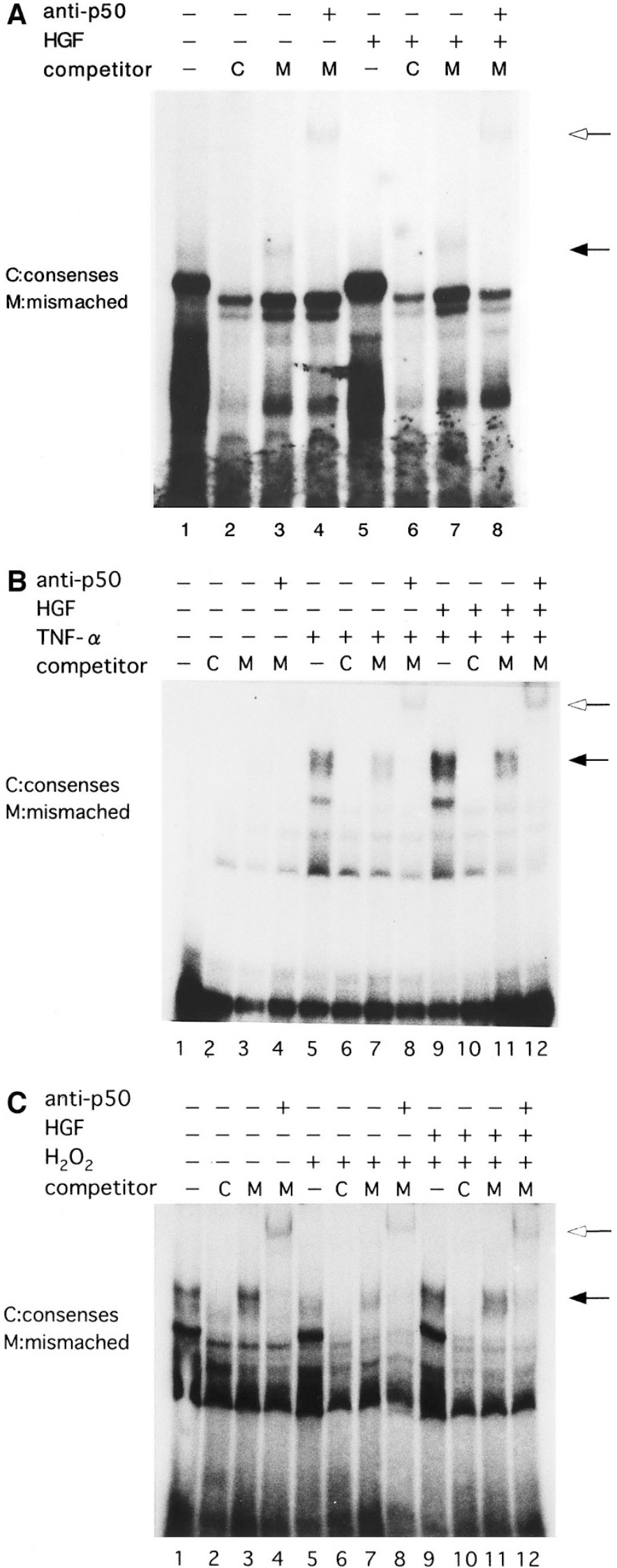

Figure 7. Analysis of HGF effect on the NF- $\kappa \mathrm{B}$ activity in SAEC. EMSA was performed as described in "Materials and Methods." Closed and open arrowheads represent bands of the NF- $\kappa \mathrm{B}$-specific and its supershifted oligonucleotides, respectively. (A) Effect of HGF on the NF- $\kappa \mathrm{B}$ activity. SAEC was in the outer mitochondrial membranes inhibit activation of caspase-3 by preventing release of cytochrome $c$, whereas apoptosis-inducing proteins such as Bax and Bad induce its release by counteracting antiapoptotic proteins $(28,29)$. We next examined changes in expression of these molecules on Western blot after $48 \mathrm{~h}$ culture with or without TNF- $\alpha$ (40 $\mathrm{ng} / \mathrm{mL})$ or $\mathrm{H}_{2} \mathrm{O}_{2}(85 \mu \mathrm{M})$ in the absence or presence of HGF $(40 \mathrm{ng} / \mathrm{mL})$. As shown in Figure 8, the Bcl-2 expression modestly increased after TNF- $\alpha$ or $\mathrm{H}_{2} \mathrm{O}_{2}$ treatment alone, and further up-regulated in the presence of HGF. The Bcl-XL expression was unchanged after $\mathrm{H}_{2} \mathrm{O}_{2}$ treatment alone, but moderately up-regulated in the presence of HGF. In contrast, the Bax expression was unchanged after TNF$\alpha$ treatment alone, but markedly down-regulated in the presence of HGF. HGF treatment alone did not affect the expression of these Bcl-2 family proteins (data not shown). Accordingly, the Bcl-2/Bax ratio of 1.7 after TNF- $\alpha$ treatment alone increased to 5.5 in the presence of $\mathrm{HGF}$, and the $\mathrm{Bcl}-\mathrm{X}_{\mathrm{L}} / \mathrm{Bax}$ ratio of 0.7 after $\mathrm{H}_{2} \mathrm{O}_{2}$ treatment alone increased to 1.1 in the presence of HGF. Thus, a protective activity of HGF against the TNF- $\alpha$ - or $\mathrm{H}_{2} \mathrm{O}_{2}$-induced apoptosis might be mediated, at least in part, by an increase in the ratio of apoptosis-suppressing to apoptosis-inducing proteins.

\section{DISCUSSION}

In the present study, we used SAEC as the in vitro model cell line to study the damage and repair of human bronchiolar epithelium, and TNF- $\alpha$ and $\mathrm{H}_{2} \mathrm{O}_{2}$ as effector mediators to mimic inflammation and oxidative stress, respectively. Airway mucosal inflammation plays a critical role in the pathogenesis of lower respiratory tract infections affecting mainly small bronchi and terminal respiratory airway, and TNF- $\alpha$ is one of the key mediators involved in the inflammatory responses (30, 31). Respiratory syncytial virus often infects infants less than $1 \mathrm{y}$ of age and induces severe bronchiolitis, which is characterized by destruction of bronchiolar epithelium, hypersecretion of mucous, and round cell infiltration resulting in the

cultured for $48 \mathrm{~h}$ in the absence (lanes $1-4$ ) or presence (lanes 5-8) of HGF $(40 \mathrm{ng} / \mathrm{mL})$. Nuclear extracts were incubated with (lanes 4 and 8 ) or without (lanes 1-3 and 5-7) anti-p50 antibody in the absence (lanes 1 and 5) or presence of 100 -fold excess of unlabeled consensus $(C$; lanes 2 and 6$)$ or mismatched $(M$; lanes 3 and 7$) \mathrm{NF}-\kappa \mathrm{B}$ oligonucleotide followed by the addition of ${ }^{32} \mathrm{P}$-labeled NF- $\kappa$ B-specific oligonucleotide. $(B)$ Effect of HGF on the NF- $\kappa$ B activity after TNF- $\alpha$ treatment. SAEC was cultured for $48 \mathrm{~h}$ without (lanes 1-4) or with (lanes 5-12) TNF- $\alpha$ in the absence (lanes 1-8) or presence (lanes 9-12) of HGF $(40 \mathrm{ng} / \mathrm{mL})$. Nuclear extracts were incubated with (lanes 4,8 , and 12) or without (lanes 1-3, 5-7, and 9-11) anti-p50 antibody in the absence (lanes 1, 4, and 9) or presence of 100-fold excess of unlabeled consensus $(C$; lanes 2,6 , and 10$)$ or mismatched $(M$; lanes $3,4,7,8,11$, and 12) NF- $\kappa \mathrm{B}$ oligonucleotide followed by the addition of ${ }^{32} \mathrm{P}$-labeled NF- $\kappa \mathrm{B}-$ specific oligonucleotide. (C) Effect of HGF on the NF- $\kappa$ B activity after $\mathrm{H}_{2} \mathrm{O}_{2}$ treatment. SAEC was cultured for $48 \mathrm{~h}$ without (lanes 1-4) or with (lanes 5-12) $\mathrm{H}_{2} \mathrm{O}_{2}$ in the absence (lanes 1-8) or presence (lanes 9-12) of HGF (40 $\mathrm{ng} / \mathrm{mL}$ ). Nuclear extracts were incubated with (lanes 4, 8, and 12) or without (lanes 1-3, 5-7, and 9-11) anti-p50 antibody in the absence or presence of 100 -fold excess of unlabeled consensus ( $C$; lanes 2, 6, and 10) or mismatched $(M$; lanes 3, 4, 7, 8, 11, and 12 ) NF- $\mathrm{BB}$ oligonucleotide followed by the addition of ${ }^{32} \mathrm{P}$-labeled $\mathrm{NF}-\kappa \mathrm{B}$-specific oligonucleotide. 


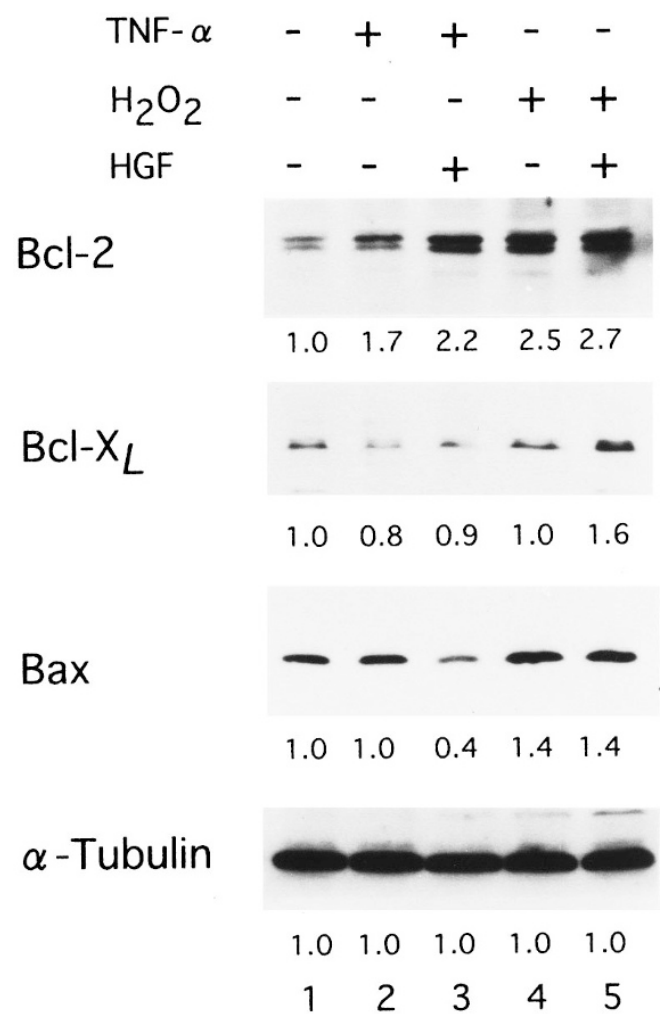

Figure 8. Western blot analysis of HGF effect on expression of Bcl-2 family members in SAEC after TNF- $\alpha$ or $\mathrm{H}_{2} \mathrm{O}_{2}$ treatment. SAEC was cultured for $48 \mathrm{~h}$ without (lane 1) or with TNF- $\alpha$ (lanes 2 and 3) or $\mathrm{H}_{2} \mathrm{O}_{2}$ (lanes 4 and 5) in the absence (lanes 1, 2, and 4) or presence (lanes 3 and 5) of HGF (40 $\mathrm{ng} / \mathrm{mL})$. Lysates $\left(5 \times 10^{5}\right.$ cells/lane $)$ were run, blotted, and stained with antibodies against $\mathrm{Bcl}-2, \mathrm{Bcl}-\mathrm{X}_{\mathrm{L}}, \mathrm{Bax}$, and $\alpha$-tubulin (control). Relative quantities of each of bands determined by densitometry are shown under each band.

formation of mucous plugs obstructing bronchioles in the process of which several inflammatory cytokines are closely implicated (32). On the other hand, hyperoxic lung injury is characterized by a cell-death response with features of apoptosis and necrosis at the level of bronchi, bronchioles, and alveoli, and is considered as one of important factors associated with the pathogenesis of chronic lung disease (CLD), previously called bronchopulmonary dysplasia, which mainly affects premature infants requiring mechanical ventilation and supplemental oxygen (33). Major features of CLD are metaplastic and/or dysplastic changes with focal emphysematous alveoli, alveolar septal fibrosis, and destruction of bronchiolar epithelium.

In animals, levels of HGF mRNA have been shown to increase in whole lung after injury caused by intratracheal instillation of hydrochloric acids or the ischemia-reperfusion procedure $(34,35)$. In humans, serum levels of HGF in pneumonia patients are significantly elevated before treatment, but decrease in those responding to the initial antibiotic therapy, whereas they remain unchanged or further increase in those not responding to the therapy, suggesting that HGF may act as an early therapeutic predictor in pneumonia $(36,37)$. HGF is also elevated in the bronchoalveolar lavage (BAL) fluid from acute respiratory distress syndrome patients with a poor prognosis, but not with a good prognosis, suggesting that HGF concen- tration in the BAL fluid reflects the severity of lung damage (38). Thus, HGF is physiologically secreted from damaged pulmonary mesenchymal cell and might be involved in the repair process of pulmonary mesenchymal and epithelial cells in a paracrine and/or autocrine fashion.

In the animal models suffering from drug-induced fulminant hepatitis and liver cirrhosis, in vivo transfer of HGF has been shown to have a potent protective activity against liver damage (39), which was also proved in the HGF gene therapy (40). However, little is known about the protective effect of exogenously administered HGF on lung damage in humans. We thus addressed the HGF effect on the TNF- $\alpha$ - or $\mathrm{H}_{2} \mathrm{O}_{2}$-induced small airway damage using the SAEC cell line, and demonstrated that treatment with TNF- $\alpha$ - or $\mathrm{H}_{2} \mathrm{O}_{2}$-induced SAEC into apoptosis in a dose-dependant manner, but the addition of HGF partially but dose-dependently protected SAEC from apoptosis. Moreover, this protective activity of HGF was evident even if added after initiation of treatment with TNF- $\alpha$ or $\mathrm{H}_{2} \mathrm{O}_{2}$, raising the possibility that administration of HGF might be clinically effective for lung injuries by inflammation and/or oxidative stress even after the damages are already proceeding. Of interest, rescued cells by HGF from the TNF- $\alpha$ - and $\mathrm{H}_{2} \mathrm{O}_{2}$-induced apoptosis showed different shapes, respectively, suggesting that HGF transmits distinct survival signals depending on apoptotic stimuli. Clarification of mechanism of morphologic changes might be important to understand survival signals delivered from HGF and remains for future study.

We also demonstrated that the rescue effect of HGF on the TNF- $\alpha$ - or $\mathrm{H}_{2} \mathrm{O}_{2}$-induced apoptosis is mediated, at least in part, by up-regulating the NF- $\kappa \mathrm{B}$ activity and an increase in the ratio of apoptosis-suppressing to apoptosis-inducing proteins expression. Uncontrolled up-regulation of the NF- $\kappa \mathrm{B}$ activity has been regarded as one of important factors involved in exacerbation of systemic or organ-specific inflammatory diseases (41, 42 ), and anti-inflammatory gene therapy to inhibit the NF- $\kappa$ B activity is expected to have a beneficial effect on these diseases (43). We showed that HGF did not affect the NF- $\kappa$ B activity in intact SAEC, but selectively up-regulated its activity in SAEC triggered into undergoing apoptosis by TNF- $\alpha$, suggesting that administration of HGF to patients with inflammatory diseases will not increase the risk of inflammation spreading into surrounding tissues. Fibrotic changes of alveoli and bronchioles in the repair process from lung injuries plays a crucial role in the pathogenesis of chronic fibrous lung diseases, including CLD in infants. It is reported that TGF- $\beta$, a central mediator of fibrosis, negatively regulates HGF secretion from mesenchymal cells and inhibits regeneration of damaged pulmonary epithelial cells by counteracting HGF activity (44), suggesting that administration of HGF will contribute to block the progression of fibrotic changes and to regenerate pulmonary epithelial cells in CLD infants. Thus, HGF is expected to have a potent protective activity in vivo against acute and chronic lung injuries induced by inflammation and/or oxidative stress.

A therapeutic approach for obstructive arterial diseases using HGF gene therapy is now clinically under preparation because it has been demonstrated that HGF has a potent angiogenic activity in vitro and in vivo (45). HGF is expected to be clinically applicable in the near future in a wide range of 
diseases as a potent cytokine mediating the healing process of damaged tissues.

\section{REFERENCES}

1. Chernick V, Boat T 1998 Kendig's Disorders of the Respiratory Tract in Children. Saunders, Philadelphia, pp 3-16

2. Nakamura T, Teramoto H, Ichihara A 1986 Purification and characterization of a growth factor from rat platelets for mature parenchymal hepatocytes in primary cultures. Proc Natl Acad Sci U S A 83:6489-6493

3. Nakamura T, Nishizawa T, Hagiya M, Seki T, Shimonishi M, Sugimura A, Tashiro K, Shimizu S 1989 Molecular cloning and expression of human hepatocyte growth factor. Nature 342:440-443

4. Bottaro DP, Rubin JS, Faletto DL, Chan AM, Kmiecik TE, Vande Woude GF, Aaronson SA 1991 Identification of the hepatocyte growth factor receptor as the c-met proto-oncogene product. Science 251:802-804

5. Omichi H, Koshimizu U, Matsumoto K, Nakamura T 1998 Hepatocyte growth facto (HGF) acts as a mesenchyme-derived morphogenic factor during fetal development. Development 125:1315-1324

6. Igawa T, Kanda S, Kanetake H, Saitoh Y, Ichikawa A, Tomita Y, Nakamura T 1991 Hepatocyte growth factor is a potent mitogen for cultured rabbit renal tubular epithelial cells. Biochem Bioph Res Commun 174:831-838

7. Sato N, Takahashi H 1997 Hepatocyte growth factor promotes growth and lumen formation of fetal lung epithelial cells in primary culture. Respirology 2:185-191

8. Yanagita K, Nagaike M, Ishibashi H, Niho Y, Matsumoto K, Nakamura T 1992 Lung may have an endocrine function producing hepatocyte growth factor in response to injury of distal organs. Biochem Biophys Res Commun 182:802-809

9. Shiratori M, Michalopoulos G, Shinozuka H, Singh G, Ogasawara H, Katyal SL 1995 Hepatocyte growth factor stimulates DNA synthesis in alveolar epithelial type II cells in vitro. Am J Respir Cell Mol Biol 12:171-180

10. Itakura A, Kurauchi O, Morikawa S, Okamura M, Furugori K, Mizutani S 1997 Involvement of hepatocyte growth factor in formation of bronchoalveolar structures in embryonic rat lung in primary culture. Biochem Biophys Res Commun 241:98103

11. Adamson IY, Bakowska J 1999 Relationship of keratinocyte growth factor and hepatocyte growth factor levels in rat lung lavage fluid to epithelial cell regeneration after bleomycin. Am J Pathol 155:949-954

12. Nakamura T, Mizuno S, Matsumoto K, Sawa Y, Matsuda H, Nakamura T 2000 Myocardial protection from ischemia/reperfusion injury by endogenous and exogenous HGF. J Clin Invest 106:1511-1519

13. Kitta K, Day RM, Ikeda T, Suzuki Y 2001 Hepatocyte growth factor protects cardiac myocytes against oxidative stress-induced apoptosis. Free Radic Biol Med 31:902910

14. Kojika S, Sugita K, Inukai T, Saito M, Iijima K, Tezuka T, Goi K, Shiraishi K, Mor T, Okazaki T, Kagami K, Ohyama K, Nakazawa S 1996 Mechanism of glucocorticoid resistance in human leukemic cells; implication of abnormal 90 and $70 \mathrm{kDa}$ hea shock proteins. Leukemia 10:994-999

15. Yamakawa-Karakida N, Sugita K, Inukai T, Goi K, Nakamura M, Uno K, Sato H, Kagami K, Barker N, Nakazawa S 2002 Ligand activation of peroxisome proliferatoractivated receptor yinduces apoptosis of leukemia cells by down-regulating the c-myc gene expression via blockade of the Tcf-4 activity. Cell Death Differ 9:513-526

16. Naldini L, Vigna E, Narsimhan RP, Gaudino G, Zarnegar R, Michalopoulos GK, Comoglio PM 1991 Hepatocyte growth factor (HGF) stimulates the tyrosine kinase activity of the receptor encoded by the proto-oncogene c-MET. Oncogene 6:501-504

17. Gual P, Giordano S, Williams T, Rocchi S, Van Obberghen E, Comoglio PM 2000 Sustained recruitment of phospholipase C- $\gamma$ to Gab 1 is required for HGF-induced branching tubulogenesis. Oncogene 19:1509-1518

18. Onishi-Haraikawa $\mathrm{Y}$, Funaki $\mathrm{M}$, Gotoh $\mathrm{N}$, Shibuya $\mathrm{M}$, Inukai $\mathrm{K}$, Katagiri $\mathrm{H}$, Fukushima Y, Anai M, Ogihara T, Sakoda H, Ono H, Kikuchi M, Oka Y, Asano T 2001 Unique phosphorylation mechanism of Gab1 using PI 3-kinase as an adaptor protein. Biochem Bioph Res Commun 288:476-482

19. Villa-Moruzzi E, Lapi S, Prat M, Gaudino G, Comoglio PM 1993 A protein tyrosine phosphatase activity associated with the hepatocyte growth factor/scatter factor receptor. J Biol Chem 268:18176-18180

20. Weidner KM, Di Cesare S, Sachs M, Brinkmann V, Behrens J, Birchmeier W 1996 Interaction between Gab1 and the c-Met receptor tyrosine kinase is responsible for epithelial morphogenesis. Nature 384:173-176

21. Mauron CR, Moscatello DK, Naujokas M, Holgado-Madruga M, Wong A, Park M 1999 A conserved inositol phospholipid binding site within the pleckstrin homology domain of the Gab1 docking protein is required for epithelial morphogenesis. J Biol Chem 274:31719-31726

22. Vinci MC, Visentin B, Cusinato F, Naridelli GB, Trevisi L, Luciani S 2004 Effect of vascular endothelial growth factor and epidermal growth factor on iatrogenic apoptosis in human endothelial cells. Biochem Pharmacol 67:277-284

23. Baud V, Karin M 2001 Signal transduction by tumor necrosis factor and its relatives. Trends Cell Biol 11:372-377

24. Varghese J, Chattopadhaya S, Sarin A 2001 Inhibition of p38 kinase reveals a TNF- $\alpha$-mediated, caspase-dependent, apoptotic death pathway in a human myelomonocyte line. J Immunol 166:6570-6577

25. Verrecchia F, Tacheau C, Wagner EF, Mauviel A 2003 A central role for the JNK pathway in mediating the antagonistic activity of pro-inflammatory cytokines against transforming growth factor- $\beta$-driven SMAD3/4-specific gene expression. J Biol Chem 278:1585-1593

26. Tang F, Tang G, Xiang J, Dai Q, Rosner M, Lin A 2002 The absence of NF- $\kappa$ Bmediated inhibition of c-Jun N-terminal kinase activation contributes to tumo necrosis factor alpha-induced apoptosis. Mol Cell Biol 22:8571-8579

27. Jaspers I, Zhang W, Fraser A, Samet JM, Reed W 2001 Hydrogen peroxide has opposing effects on IKK activity and $\mathrm{I} \kappa \mathrm{B} \alpha$ breakdown in airway epithelial cells. Am J Resp Cell Mol Biol 24:769-777

28. Gross A, McDonnell JM, Korsmeyer SJ 1999 Bcl-2 family members and the mitochondria in apoptosis. Genes Dev 13:1899-1911

29. Zamzami N, Kroemer G 2003 Apoptosis: mitochondrial membrane permeabilization-the (w) hole story? Curr Biol 13:R71-R73

30. Driscoll KE 2000 TNF alpha and MIP-2: role in particle-induced inflammation and regulation by oxidative stress. Toxicol Lett 112-113:177-183

31. Laskin DL, Heck DE, Laskin JD 1998 Role of inflammatory cytokines and nitric oxide in hepatic and pulmonary toxicity. Toxicol Lett 102-103:289-293

32. Chernick V, Boat T 1998 Kendig's Disorders of the Respiratory Tract in Children. Saunders, Philadelphia, pp 518-526

33. Groneck P, Speer CP 1997 Pulmonary inflammation in the pathogenesis of bronchopulmonary dysplasia. Pediatr Pulmonol Suppl 16:29-30

34. Yanagita K, Matsumoto K, Sekiguchi K, Ishibashi H, Niho Y, Nakamura T 1993 Hepatocyte growth factor may act as a pulmotrophic factor on lung regeneration after acute lung injury. J Biol Chem 268:21212-21217

35. Liu XL, Sato S, Dai W, Yamanaka N 2001 The protective effect of hepatocyte growth-promoting factor (pHGF) against hydrogen peroxide-induced acute lung injury in rats. Med Electron Microsc 34:92-102

36. Nayeri F, Nilsson I, Skude G, Brudin L, Soderstrom C 1998 Hepatocyte growth factor (HGF) in patients with pneumonia: a comparison between survivors and nonsurvivors. Scand J Infect Dis 30:405-409

37. Nayeri F, Brudin L, Darelid J, Nilsson I, Fryden A, Soderstrom C, Forsberg P 2002 Hepatocyte growth factor may act as an early therapeutic predictor in pneumonia. Scand J Infect Dis 34:500-504

38. Stern JB, Fierobe L, Paugam C, Rolland C, Dehoux M, Petiet A, Dombret MC, Mantz J, Aubier M, Crestani B 2000 Keratinocyte growth factor and hepatocyte growth factor in bronchoalveolar lavage fluid in acute respiratory distress syndrome patients. Crit Care Med 28:2326-2333

39. Kaibori M, Inoue T, Oda M, Naka D, Kawaguchi T, Kitamura N, Miyazawa K, Kwon AH, Kamiyama Y, Okuyama T 2002 Exogenously administered HGF activato augments liver regeneration through the production of biologically active HGF. Biochem Bioph Res Commun 290:475-481

40. Fujimoto J 2000 Gene therapy for liver cirrhosis. J Gastroenterol Hepatol 15:D33D36

41. Baeuerle PA, Baltimore D 1996 NF- $\kappa$ B: ten years after. Cell 87:13-20

42. Baldwin Jr AS 1996 The NF- $\kappa \mathrm{B}$ and $\mathrm{I} \kappa \mathrm{B}$ proteins: new discoveries and insights Annu Rev Immunol 14:649-683

43. Griesenbach U, Scheid P, Hillery E, de Martin R, Huang L, Geddes DM, Alton EW 2000 Anti-inflammatory gene therapy directed at the airway epithelium. Gene Ther 7:306-313

44. Matsumoto K, Tajima H, Okazaki H, Nakamura T 1992 Negative regulation of hepatocyte growth factor gene expression in human lung fibroblasts and leukemic cells by transforming growth factor-beta 1 and glucocorticoids. J Biol Chem 267:24917-24920

45. Taniyama $\mathrm{Y}$, Morishita R, Aoki M, Nakagami H, Yamamoto K, Yamazaki K, Matsumoto K, Nakamura T, Kaneda Y, Ogihara T 2001 Therapeutic angiogenesis induced by human hepatocyte growth factor gene in rat and rabbit hindlimb ischemia models: preclinical study for treatment of peripheral arterial disease. Gene Ther 8:181-189 